\title{
Effect Of Performance Expectancy And Social Influence On Continuance Intention In OVO
}

\author{
Zoel Hutabarat ${ }^{1,}$, , Ian Nurpatria Suryawan ${ }^{2}$, Richard Andrew ${ }^{3}$, , Februarga Padua \\ Akwila ${ }^{4}$ \\ ${ }^{1}$ Strategic Management Doctoral Program Student at Universitas Trisakti, Lecturer in \\ Management at Universitas Pelita Harapan, Banten, Indonesia \\ ${ }^{2}$ Strategic Management Doctoral Program Student at Universitas Trisakti, Lecturer in \\ Management at Trisakti School of Management, Jakarta, Indonesia \\ ${ }^{3}$ Business Management Program, Faculty of Economics \& Business, Universitas Tarumanagara, \\ Jakarta, Indonesia \\ ${ }^{4}$ Bachelor of Management Student at Universitas Pelita Harapan, Banten, Indonesia
}

\author{
Email address: \\ zoel.hutabarat@uph.edu (Zoel Hutabarat) \\ ${ }^{*}$ Corresponding author
}

\begin{abstract}
The development of online transactions is driving the development of technology in payment systems. One of the most popular electronic money services in Indonesia is OVO. Behind OVO's rapid market share growth, system maintenance problems often arise that often occur without notice and are of long duration. This phenomenon is a doubt of consumers to continue to use OVO in the long term going forward because it does not match expectations and consequently consumers will look for alternative payments. This experience makes consumers unable to feel the price saving program offered and consequently consumers become dissatisfied. This study used a sample of 200 respondents, with a purposive sampling method, and with a questionnaire of 24 indicators. The result found that there is the influence of performance expectancy, social influence on continuance intention. Meanwhile there is no relation to variable effort expectancy, price saving orientation and facilitating conditions to continuance intention.
\end{abstract}

Keywords: performance expentancy, social influence, continuance intention.

\begin{abstract}
Abstrak: Perkembangan transaksi daring mendorong berkembangnya teknologi dalam sistem pembayaran. Salah satu layanan uang elektronik terpopuler di Indonesia adalah OVO. Di balik pertumbuhan pangsa pasar OVO yang pesat, sering timbul masalah pemeliharaan sistem yang sering terjadi tanpa pemberitahuan dan berlangsung lama. Fenomena ini dapat menjadi keraguan konsumen untuk menggunakan OVO dalam jangka panjang kedepannya karena tidak sesuai ekspektasi dan akibatnya konsumen akan mencari alternatif pembayaran lain. Pengalaman yang tidak nyaman ini membuat konsumen tidak dapat merasakan program penghematan harga yang ditawarkan dan akibatnya konsumen menjadi tidak puas. Penelitian ini menggunakan sampel sebanyak 200 responden, dengan metode purposive sampling, dan dengan angket sebanyak 24 indikator. Hasil penelitian menemukan bahwa ada pengaruh ekspektasi kinerja, pengaruh sosial terhadap niat berkelanjutan. Sedangkan variabel ekspektasi usaha, orientasi penghematan harga, dan kondisi yang dipermudah tidak ada hubungannya dengan niat berkelanjutan.
\end{abstract}


Kata kunci: ekspektasi kinerja, pengaruh sosial, niat berkelanjutan.

\section{INTRODUCTION}

The growth of online transactions is driving the development of technology in payment systems very quickly. This condition is in line with Bank Indonesia's program which supports the use of GNNT (Gerakan Nasional Non Tunai) non-cash payment instruments (Indrawati and Putri, 2018). One of the most popular non-cash payment system applications in Indonesia is OVO. This application can save electronic money up to ten million Rupiah. This application can be used for various payment purposes such as electricity payments, e-commerce payment, data packages, both prepaid and postpaid, BPJS fees, cable TV, insurance premiums to environmental fees.

In addition, the OVO application can also be used as a channel of payment in several e-commerce applications such as Grab and Tokopedia. This application makes opportunities for millions of Grab and Tokopedia users to make transactions more practical and secure. This channel of payment has also been present for Micro, Small and Medium Enterprises (MSME). Until November 2018, there were one hundred and eighty thousand MSMEs that had been joined by this digital wallet. Lot of the users can make this application as one of the most frequently used channels of payment in the future.

OVO started to become one of the unicorn companies in Indonesia because its strategic cooperation with other unicorn companies such as Grab and Tokopedia. PT Visionet Internasional, which oversees OVO, says there has been a significant growth of users since it first started operating in November 2017. Within just one year since its establishment, namely the end of November 2018, the OVO user base has grown by more than four hundred percent which downloaded of one hundred and fifteen million times. OVO Director, Harianto Gunawan said, in a year, OVO applications reach almost ninetythree percent of districts in Indonesia and as many as thirty-three percent of OVO users are in the Greater Jakarta area (Movanita, 2018).

But as a technology company that relies on equipment and Artificial Intelligence (AI), device maintenance systems are important. Some technology-based companies have system problems experienced, including OVO. This disappointment user experience were delivered on social media such as Twitter, Instagram, and other channels. As a new technology-based startup company, OVO is certainly very concerned about this condition because this will affect the user experience using the application and can ultimately affect the number of application users themselves.

This phenomenon can be a bad brand exposure for costumers to continue using OVO in the future (continuance intention). Costumers who expect OVO performance according to their expectations become disappointed when OVO cannot be used (performance expectancy). Costumers who had intended to pay with OVO but apparently could not be used could make consumers look for other payment alternatives (effort expectancy). Costumers who expect cashback from OVO payments become not getting cashback (price saving orientation). Costumers who were satisfied with OVO payments and referred to people around them became dissatisfied because they could not be used for a while without prior notice of maintenance (social influence). At the same time, 
consumers do not get alternative facilities to pay with OVO when OVO performs maintenance and is not given information about it (facilitating conditions).

From the Twitter application with \#error or \#undermaintaninance for similar payment applications like Gopay and Dana, the OVO application experienced a significant number of complaints in 2019 where most of these complaints were not usable by all users, not payment failures experienced by each individual user. This study is a modification of research conducted by (Palau-Saumell et al., 2019) conducted in Malaysia. This study wants to see whether the results obtained are the same as previous studies in electronic payment of OVO users in Indonesia.

\section{THEORITICAL REVIEW}

Integrated Theory of Acceptance and Use of Technology. The UTAUT-1 theory is a combination of various theories such as Theory of Reasoned Action (TRA), Technology Acceptance Model, Motivational Model, Theory of Planned Behavior, Decomposed Theory of Planned Behavior, Model of PC Utilization, Innovation Diffusion Theory, and Social Cognitive Theory. . UTAUT-1 tries to explain the process of knowledge absorption and implementation of information technology through four main variables, namely: expectations of company performance, efforts to be made, social impact, and supportive facilities (Palau-Saumell et al., 2019).

The three variables mentioned above, namely performance, effort, and social impact, affect the company's intention to use existing technology, and the last variable affects the company in using the technology itself. In addition, the relationship between the company's intention to use technology and the use of technology in the company was moderated by control variables, namely, gender, age, consumer experience in using the technology, and voluntary use. Research like this has been applied in several research contexts, such as the acceptance of internet technology in the banking industry by bank employees, acceptance and use of social networking sites by students, use and utilization of tourist sites in rural areas, and also application of applications for tour guides. UTAUT2 , which is an advanced version of UTAUT-1, was formed with the aim of being able to better adapt to consumer needs, and also added three complementary variables, namely: hedonic motivation, orientation towards price savings, and consumer habits.

The variables of hedonic motivation and orientation towards price savings are included in the intention to use technology, while consumer habits are only limited to the intention to use technology. UTAUT-2 theory covers the relationship between the condition of the facilities used and the intention to use the technology. UTAUT-2 theory also raises new variables and relationships, namely, experience as a moderator in the relationship between the intention to use technology and the use of technology. The UTAUT-2 theory decides that the variables of expectations for company performance, the efforts to be made, social impact, hedonic motivation, orientation towards price savings, and consumer habits all together influence behavioral intentions to use technology. meanwhile, the intention to use technology, the conditions of the facilities that support it, and consumer habits have an influence on consumer use behavior. 


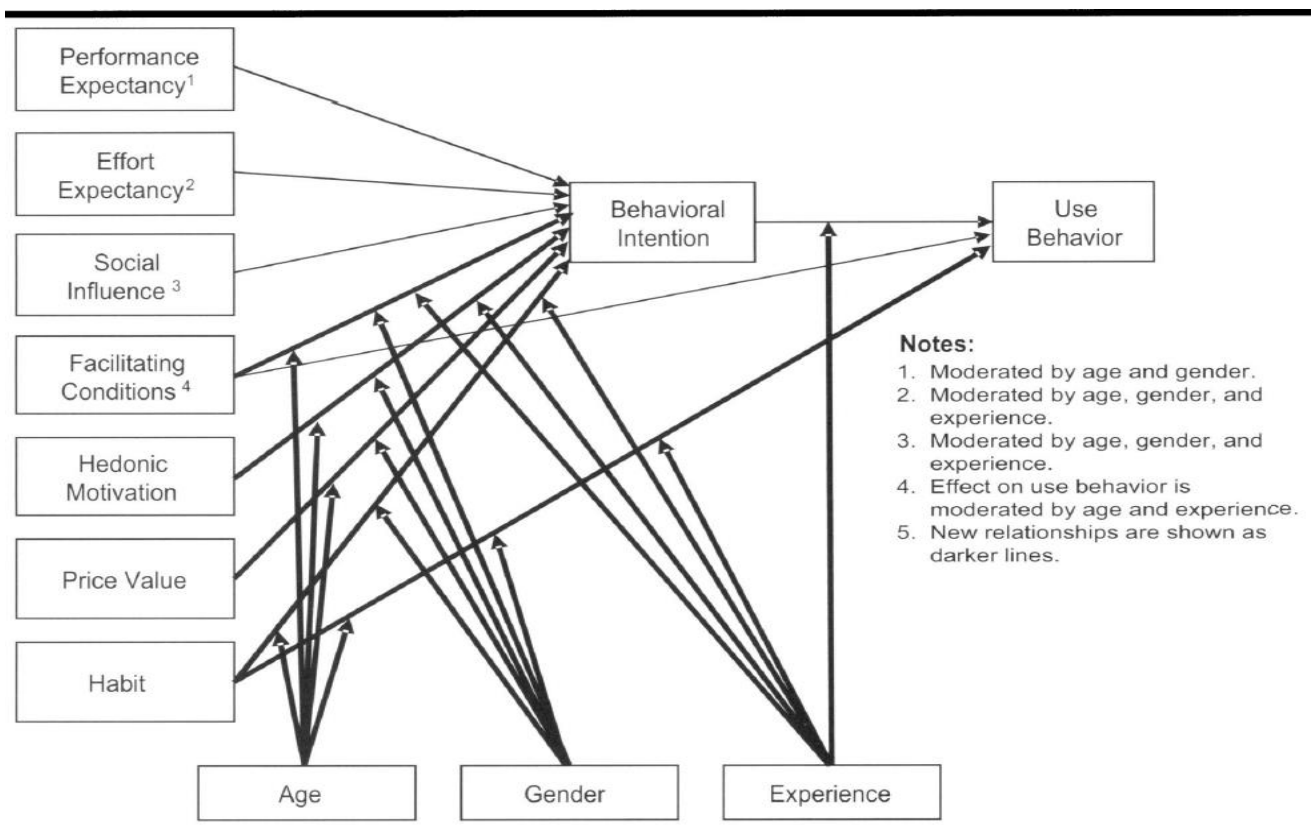

Figure 1. UTAUT 2

Source: (Venkatesh et al., 2016)

Performance Expectancy. Performance expectancy can be defined as the extent to which users expect the use of the system will help to benefit in job performance (Williams et al., 2015). More concretely this means that people are more likely to adopt new technology when they believe it will help them to do their jobs (Trybou, 2017). (Venkatesh et al., 2016) integrate five concepts from various models into performance expectancy variables, namely, first, perceived usefulness. According to Venkatesh et al. (2016), perceived usefulness is defined as how far a person believes that using a particular system will improve performance.

The variables of this study are in the research of (Williams et al., 2015) and (Martins et al., 2014), extrinsic motivation according to (Venkatesh et al., 2016). Second, extrinsic motivation is defined as the perception desired by the user to carry out an activity because it is considered as a tool in achieving valuable results that are different from the activity itself, such as work performance, payments, and promotions. This research variable is found in the research of (Martins et al., 2014). Third, job suitability. According to (Venkatesh et al., 2016), job suitability is defined by how the capabilities of a system improve individual work performance.

This research variable is found in the research of (Martins et al., 2014). Fourth, the relative advantage. According to (Venkatesh et al., 2016), relative advantage is defined by the extent to which the use of innovation is perceived better than using its predecessor. This research variable is found in the research of (Alazzam, 2015). Fifth, outcome expectations. According to (Venkatesh et al., 2016), outcome expectations are related to the consequences of behavior.

Based on empirical evidence, performance expectations in the company are separated into performance expectations from a firm perspective and performance expectations from a personal perspective. Performance research variables within 
companies and individuals can be seen in research conducted by (Martin and Guerrero, 2020). (Williams et al., 2015) defines the usefulness of technological knowledge as the degree to which consumers or individuals believe that the use of knowledge, especially in technology, can help improve one's work performance. From the above explanation, it can be concluded that a person's trust in the use of information technology will be very beneficial for himself and can improve job performance and performance.

Effort Expectancy. According to (Venkatesh et al., 2016) hopes that the efforts made are all efforts of companies or individuals to accept and adopt new knowledge at various levels of convenience in connection with the use of any technology system. This variable has similarities with the variable perception of ease of use and use in the Technology Acceptance Model (TAM), and has similarities with the variable complexity in the PC Utilization Model (MPCU), and is also similar to the actual ease of use variable in the Innovation Diffusion Theory (IDT) theory. ) (Rogers et al., 2019). According to (Williams et al., 2015) understanding the perception of the ease of use of technology or new knowledge is the extent to which a person believes that using a system will not require a large amount of effort. It follows from the definition of ease of use, free from difficulty and vigorous effort. Effort is the total work done to achieve a specific goal.

According to (Wang, 2014) complexity is defined as the extent to which an innovation is perceived as a relative level of difficulty to be used. Then in the theory of Innovation Diffusion Theory (IDT), the actual ease of use variable is defined as the level of difficulty to utilize innovation (Alazzam, 2015). This means that effort expectancy refers to the effort required to use the system, whether it is simple or complicated. With the existence of easy technology, it can be easily accepted and adopted by users. Most users prefer technology that gives flexibility, usability and ease of use (Catherine et al., 2017).

Price Saving Orientation. The price saving orientation is a new variable introduced in UTAUT 2 theory to replace the price value variable. The price value variable proposed by (Lien et al., 2015), has a meaning as a cognitive exchange between the benefits felt by users or consumers from the technology or application used compared to the monetary costs incurred by consumers for using it. Consumers are always looking for ways to save or reduce the price charged to them through discounts because they are very concerned about the amount of money they spend and what they can save through this discount (Seiler, 2013). Another study conducted by (Kahneman and Tversky, 2018) revealed that consumers are willing to travel long distances just to get discounts offered by stores through the products they sell. The effectiveness of the discount program is also supported by other research that states that price discounts will have an influence on the perceived value of a product offering. This shows that discounted prices are a better offer (Yeo et al., 2017).

With a lower pricing strategy, it will encourage sales for a company and higher discounts can have an impact on increasing the value of certain products for consumers (Liu and Lee, 2016). The orientation of price savings does not only consider the financial savings factor but can also be seen from the perspective of the absence of additional costs to buy products or use services (Venkatesh et al., 2016; Rodríguez and Trujillo, 2013). 
Social Influence. Social influence is defined as the extent to which an individual considers something to be important because of the influence of relatives, peers, subordinates and superiors who believe that he must use a new system (Venkatesh et al., 2016). Social influence is a variable adopted from previous studies, namely: subjective norm (Martins et al., 2014), social factors (Wang, 2014), and image (Alazzam, 2015). According to (Martins et al., 2014) subjective norm is a person's perception that most people who are important to him think he should or should not conduct a behavior.

Then social factors according to (Wang, 2014), are the internalization of individuals from cultural reference groups, and interpersonal agreements that have been made by individuals with others, in certain social situations. And image according to (Alazzam, 2015), is the extent to which the use of an innovation is felt to improve one's image or status in the social system. This study considers that most users tend to make their decisions dependent on others, therefore social influence must play a more important role (Catherine et al., 2017).

Facilitating Condition. Facilitating conditions refer to the extent to which people believe that organizational and technical infrastructure exists to support the system (Venkatesh et al., 2016). This variable also has similarities with other research variables, namely: perceived behavioral control (Rizzo and Columna, 2020), facilitating conditions (Wang, 2014), and compatibility (Alazzam, 2015).

Perceived behavioral control according to (Rizzo and Columna, 2020), reflects the perception of internal and external barriers to behavior and includes self-efficacy, conditions of resource facilitation, and conditions of technological facilitation. Then facilitating conditions according to (Wang, 2014), are objective factors in the environment agreed upon by observers making actions easy to do, including providing computer support. And finally, compatibility tells (Alazzam, 2015), is the extent to which innovation is considered consistent with the values, needs, and experiences of potential adopters.

Continuance Intention. The Expectation disconfirmation theory (EDT) model is the most well-known model in the study of consumer behavior and is a source of reading in the marketing field that is able to explain post-consumption consumer behavior (Elkhani \& Bakri, 2016; Lankton et al., 2016). According to the EDT model, statements about how consumers consume something will affect user satisfaction (Lankton et al., 2016). Consumer statements are a perspective built by consumers after consumers compare expectations before consumers make a purchase to performance after consumers buy a product or service that is consumed (Lankton et al., 2016).

When the expectations for products purchased by consumers are met, dissatisfaction does not occur so this condition will lead to consumer satisfaction. Consumers who are satisfied with the product purchased will have a higher chance for these consumers to repurchase the same product or service or other derivative products in the future. When the expectations for a product purchased and felt by consumers are below the expectations of consumers, a sense of dissatisfaction will arise, which will contribute to consumer dissatisfaction with the product or service. In the future, dissatisfied consumers will not buy or use the same products or services. The expectation of a product or service that is felt by consumers is an important factor in the EDT model. In fact, before consumers buy 
a product or service, consumers already have certain expectations about the product or service they want to buy.

When consumers use or consume a purchased product or service, the level of consumer expectations will determine the level of satisfaction and repurchase intention in the future. Because expectations play an important role in consumption behavior, a study by (Susanto et al., 2016), has used expectations to evaluate performance. Continuity of intention is the extent to which a person plans to continue doing something in the future (Indrawati and Putri, 2018). In the UTAUT-2 model, there are several variables that can influence the sustainability intention in terms of absorption and use of new technology. These variables such as expectations of company or individual performance, expectations of efforts made to achieve certain goals, social impact for individuals and the environment, conditions for supporting facilities, motivation for a hedonic lifestyle, oriented towards discounting, habits or culture, and perceptions. credibility. However, this study takes several of these variables as research objects, namely: expectations of company or individual performance, expectations of efforts made to achieve certain goals, social impact for individuals and the environment, supportive facility conditions, and discount-oriented orientation.

Relationship Between Variables. Performance expectancy can be defined as the extent to which the user expects that using the system will help him to benefit in job performance (Venkatesh et al., 2016). As in research on continuance intention towards restaurant reservation applications in Spain conducted by (Palau-Saumell et al., 2019), concluded that there is a positive relationship between performance expectancy that affects continuance intention. Then in a study conducted by (Savitri and Indrawati, 2019), also concluded that performance expectancy positively influences continuance intention. And also, in research on the factors that influence GOPAY continuance intention where (Indrawati and Putri, 2018) concluded that the performance expectancy hypothesis positively influences continuance intention positively.

H1: There is a positive relationship between performance expectancy and continuance intention.

Effort expectancy is the level of convenience associated with the use of consumer technology. Previous studies conducted by (Palau-Saumell et al., 2019) on the factors that influence continuance intention in restaurant reservation applications concluded that there was a positive relationship between effort expectancy and continuance intention. Then there is also a reference article which is a study conducted by (Savitri and Indrawati, 2019), concluding that effort expectancy affects continuance intention. And subsequent research examining continuance intention in GOPAY users, (Indrawati and Putri, 2018), concluded that effort expectancy influences continuance intention to use GOPAY positively.

H2: There is a positive relationship between effort expectancy and continuance intention.

According to a research article by (Venkatesh et al., 2016), there is a price saving orientation variable that positively influences the intention to use technology. Price saving 
orientation refers to consumers' perceptions of the perceived benefits and the costs they incur. Based on previous research in an article examining the use of restaurant reservation applications by (Palau-Saumell et al., 2019), which concluded that the price saving orientation affects the continuance intention of users of mobile apps reservations. And the article that discusses continuance intention on the use of GO-PAY where (Indrawati and Putri, 2018), concluded that the price saving orientation positively affects the dependent variable continuance intention of GO-PAY usage. Then research conducted by (Savitri and Indrawati (2019), has the conclusion that there is a positive relationship between price saving orientation and continuance intention.

H3: There is a positive relationship between price saving orientation and continuous intention.

In this study, articles have been found that support the hypothesis to be used, namely a previous research article from Spain that examined the continuance intention of a restaurant reservation application, where (Palau-Saumell et al., 2019), concluded that social influence variables influence continuance intention positively. Then research conducted by (Indrawati and Putri, 2018), about continuance intention on GO-PAY customers concluded that social influence variables as variables that affect continuance intention positively. And the last article supporting this hypothesis is an article by (Savitri and Indrawati, 2019), concluding that social influence variables that influence continuance intention positively.

H4: There is a positive relationship between social influence and continuance intention.

Facilitating conditions refer to the extent to which people believe that organizational and technical infrastructure exists to support the system (Venkatesh et al., 2016). Many scholars find that facilitating conditions have a positive effect on the use of technology. One of them is an article conducted by (Palau-Saumell et al., 2019), states that there is a positive relationship between the variables facilitating condition and continuance intention on mobile apps restaurant reservation in Spain. Then an article by (Savitri and Indrawati, 2019), has the conclusion that the facilitating condition variable influences continuance intention positively. This is also supported by articles written by (Indrawati and Putri, 2018), which discusses the use of GO-PAY which concludes that there is a positive relationship between the variables facilitating condition and continuance intention.

H5: There is a positive relationship between facilitating conditions and continuous intention. 


\section{RESEARCH MODEL}

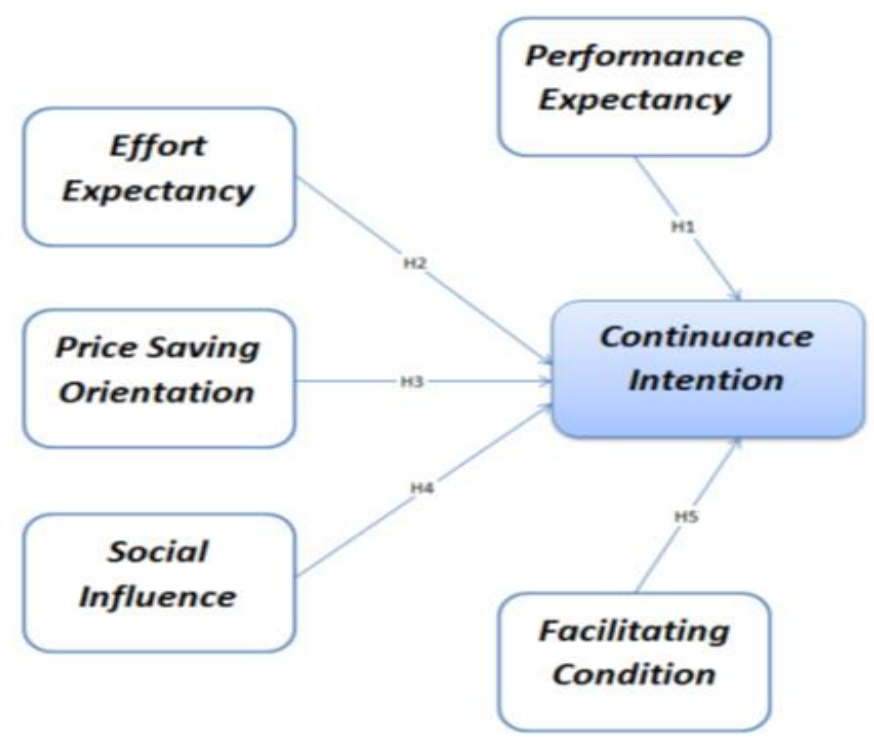

Figure 1. Research Model

Source: (Palau-Saumell et al., 2019)

\section{METHODS}

This research uses non-probability sampling with purposive sampling. Purposive sampling is a sampling technique that is used quite often. This method uses criteria that have been selected by researchers in selecting samples. Sample selection criteria are divided into inclusion and exclusion criteria. The sample size were 200 respondents distributed to all OVO user students at Universitas Bina Nusantara, Universitas Multimedia Nusantara, Universitas Prasetya Mulia and Universitas Pelita Harapan.

This research was conducted by distributing online based questionnaires, google form, to students from 4 universities consisting of Pelita Harapan University, Prasetya Mulya University, Multimedia Nusantara University, Bina Nusantara University with a range of ages $18-22$ years. The return rate for all questionnaires was $83.68 \%$. This study obtained 239 respondents, and 200 respondents were randomly used for processing.

Sixty five respondents obtained from Universitas Pelita Harapan, 47 respondents obtained from Universitas Prasetiya Mulia, 41 respondents obtained from Universitas Multimedia Nusantara, 38 respondents obtained from Bina Nusantara while the rest taken without detailed university location.

\section{Operational Definitions}

Performance Expectancy:

(1) I think OVO is very practical for making daily payments.

(2) In my opinion, using OVO will save time in making payments.

(3) I feel safer paying with OVO than paying by cash.

(4) Using OVO will be more productive than cash (less effort). 
Effort Expectancy:

(1) I find it easy when I learn to operate the OVO application.

(2) Interaction with OVO application is easy to understand.

(3) I feel that I don't need special abilities to use the OVO application.

(4) Easy for me to understand in using the OVO application.

Price Saving Orientation:

(1) I get a voucher / coupon on the OVO application.

(2) I get a premium offer. (Example: When getting a Platinum Privileges Member).

(3) OVO offers discounted prices. (Example: When paying Grab-Ride / Grab-Car get a discounted price compared to paying in cash).

(4) OVO offers an attractive cashback.

Social Influence:

(1) My close friends suggest that I should use OVO.

(2) Community make me think that I must use OVO.

(3) Circumstances around me use OVO for payments. (Example: parking fees, shopping at supermarkets, credit fees, and transportation costs)

(4) Many people around me already have OVO applications.

Facilitating Condition:

(1) I believe that the smartphone that I have can be used for the OVO application.

(2) I believe that I have enough knowledge in operating OVO applications.

(3) I feel comfortable using the OVO application.

(4) OVO management aids when customers have difficulties.

Continuance Intention:

(1) I intend to always use OVO.

(2) I will continue to use OVO regularly.

(3) I continue use OVO instead of using other payment instruments.

(4) I would suggest others use the OVO application.

\section{RESULTS}

Respondent Profile. This research was conducted by distributing questionnaires based on online google form to students and active students from 4 universities consisting of Pelita Harapan University, Prasetya Mulya University, Multimedia Nusantara University, Bina Nusantara University and several non-student respondents with range of age of 18-22 years. Return rate for all questionnaires was $83.68 \%$. This study obtained 239 respondents, we randomly selected 200 respondents to be processed. 
Table 1. Respondent Profile

\begin{tabular}{c|l|c}
\hline No & \multicolumn{1}{|c|}{ Universities } & Respondents \\
\hline 1 & Universitas Pelita Harapan & 70 \\
\hline 2 & Universitas Prasetya Mulya & 47 \\
\hline 3 & Universitas Multimedia Nusantara & 50 \\
\hline 4 & Universitas Bina Nusantara & 33 \\
\hline & Total & 200 \\
\hline
\end{tabular}

Descriptive Statistic, Validity, dan Reliability. The Corrected Item-Total Correlation value in the item total statistics table is a validity value. While the value of Croncbach's Alpha if Deleted Item is the value of reliability. To assess whether the values above (valid and reliable) are valid and reliable, compare them with table $\mathrm{R}$ at $\mathrm{DF}=\mathrm{N}-2$ and Probability 0.05 . The calculated $\mathrm{R}$ formula is $\mathrm{R}(\alpha ; \mathrm{df}) \mathrm{DF}=200-2$ and the probability of 0.05 is 0.1388 . If the calculated $\mathrm{R}$ Corrected Item-Total Correlation is greater than the $\mathrm{R}$ table, the variable is said to be valid. If $\mathrm{R}$ count Croncbach's Alpha if the Deleted Item is greater than the $\mathrm{R}$ table, the variable is said to be reliable. The table below is arranged based on the calculated $\mathrm{R}$ value as a Corrected Item-Total Correlation representation and the $\mathrm{R}$ table represents the calculated $\mathrm{R}$ value $(\alpha ; \mathrm{df}) \mathrm{DF}=200-2$ with a probability of 0.05 .

Table 2. Descriptive Statistic, Validity and Reliability

\begin{tabular}{|c|c|c|c|c|}
\hline Variables & Mean & $\begin{array}{c}\text { Corrected Item } \\
\text { Correlation }\end{array}$ & Cronbach Alpha & R table \\
\hline \multicolumn{5}{|c|}{ Performance Expectancy } \\
\hline PerfExp1 & 4,40 & 0,668 & 0,923 & 0,1388 \\
\hline PerfExp2 & 4,15 & 0,570 & & 0,1388 \\
\hline PerfExp3 & 4,04 & 0,553 & & 0,1388 \\
\hline PerfExp4 & 4,26 & 0,652 & & 0,1388 \\
\hline \multicolumn{5}{|c|}{ Effort Expectancy } \\
\hline EffExp1 & 3,84 & 0,390 & 0,926 & 0,1388 \\
\hline EffExp2 & 3,81 & 0,325 & & 0,1388 \\
\hline EffExp3 & 4,30 & 0,462 & & 0,1388 \\
\hline EffExp4 & 4,26 & 0,487 & & 0,1388 \\
\hline \multicolumn{5}{|c|}{ Price Saving Orientation } \\
\hline PSO1 & 4,43 & 0,648 & 0,924 & 0,1388 \\
\hline $\mathrm{PSO} 2$ & 4,36 & 0,661 & & 0,1388 \\
\hline PSO3 & 4,36 & 0,558 & & 0,1388 \\
\hline PSO4 & 4,44 & 0,633 & & 0,1388 \\
\hline \multicolumn{5}{|l|}{ Social Influence } \\
\hline SocInf1 & 3,94 & 0,645 & 0,923 & 0,1388 \\
\hline SocInf2 & 3,84 & 0,568 & & 0,1388 \\
\hline SocInf3 & 4,35 & 0,610 & & 0,1388 \\
\hline SocInf4 & 4,51 & 0,533 & & 0,1388 \\
\hline \multicolumn{5}{|c|}{ Facilitating Condition } \\
\hline FaCon1 & 4,63 & 0,511 & 0,922 & 0,1388 \\
\hline FaCon2 & 4,51 & 0,550 & & 0,1388 \\
\hline FaCon3 & 4,27 & 0,773 & & 0,1388 \\
\hline FaCon4 & 3,90 & 0,539 & & 0,1388 \\
\hline \multicolumn{5}{|c|}{ Continuance Intention } \\
\hline CI1 & 3,76 & 0,674 & 0,922 & 0,1388 \\
\hline $\mathrm{CI} 2$ & 3,80 & 0,715 & & 0,1388 \\
\hline
\end{tabular}




\begin{tabular}{ccccc}
\hline Variables & Mean & $\begin{array}{c}\text { Corrected Item } \\
\text { Correlation }\end{array}$ & Cronbach Alpha & R table \\
\hline CI3 & 3,78 & 0,661 & 0,1388 \\
CI4 & 3,54 & 0,595 & 0,1388 \\
\hline
\end{tabular}

Source: SPSS (2019)

In the table above it can be seen that the calculated $R$ value is greater than the $R$ table value, both for validity and reliability. So, it can be concluded that the variables stated above are valid and reliable. If the significance value $<0.05$, or $\mathrm{T}$ arithmetic $>\mathrm{T}$ table then there is the influence of variable X on the variable Y (Raharjo, 2019b). If the significance value $>0.05$, or $\mathrm{T}$ arithmetic $<\mathrm{T}$ table then there is no effect of variable $\mathrm{X}$ on variable Y (Raharjo, 2019b).

Table 3. T-test Results

\begin{tabular}{lcc}
\hline \multicolumn{1}{c}{ Continuance Intention } & T test & Significance \\
\hline PerfExp & 5,310 & 0,000 \\
EffExp & 1,324 & 0,187 \\
PriSavOri & 1,086 & 0,279 \\
SocInf & 4,521 & 0,000 \\
FaCon & $-1,097$ & 0,274 \\
\hline Source: SPSS (2019) & &
\end{tabular}

The significance value for the effect of performance expectancy on continuance intention is $0,000<0.05$ and the calculated $\mathrm{T}$ value is $5.310>\mathrm{T}$ table 1.972 . So, it can be concluded that $\mathrm{H} 1$ is accepted which means there is a positive influence on performance expectancy on continuance intention. The significance value for the effect of effort expectancy on continuance intention is $0.187>0.05$ and the value of $\mathrm{T}$ is $1.324<\mathrm{T}$ table 1.972. So, it can be concluded that $\mathrm{H} 2$ is rejected which means there is no positive effect of effort expectancy on continuance intention.

The known significance value for the effect of price saving orientation on continuance intention is $0.279>0.05$ and the calculated value is $1.086<\mathrm{T}$ table 1.972 . So, it can be concluded that $\mathrm{H} 3$ is rejected which means there is no positive effect of price saving orientation on continuance intention. The significance value for the influence of social influence on continuance intention is $0.000<0.05$ and the value of $t$ arithmetic $4.521>\mathrm{T}$ table 1.972. So, it can be concluded that $\mathrm{H} 4$ is accepted which means there is a positive social influence on continuance intention.

The known significance value for facilitating condition effect on continuance intention is $0.274>0.05$ and $\mathrm{T}$ count value $-1.079>$ table $\mathrm{T}-1.972$, so it can be concluded that $\mathrm{H} 5$ is rejected which means there is no positive effect of facilitating condition on continuance intention. If the significance value $<0.05$ or $\mathrm{F}$ arithmetic $>\mathrm{F}$ table then there is the effect of variable $\mathrm{X}$ on the variable $\mathrm{Y}$ simultaneously. But if the significance value $>$ 0.05 or $\mathrm{F}$ arithmetic < $\mathrm{F}$ table then there is no effect of variable $\mathrm{X}$ simultaneously on the variable $\mathrm{Y}$. F table seen with $\mathrm{F}(\mathrm{K} ; \mathrm{N}-\mathrm{K})$. The table value $\mathrm{F}$ is $\mathrm{F}(5.195)=2.26$. From the ANOVA table, the significance value is $0,000<0.05$ and $\mathrm{F}$ count is $39.485>\mathrm{F}$ table is 2.26. This means that the variables PE, EE, PSO, SI, and FC simultaneously influence the CI variable. 
It can be concluded that the R-square value is 0.504 . This means that the variable performance expectancy, effort expectancy, price saving orientation, social influence, and facilitating conditions affect the continuance intention variable by $50.4 \%$. In addition, the remaining $49.6 \%$ is influenced by other factors.

\section{DISCUSSION}

Performance Expectancy can be said have significant effect on Continuance Intention. This results same with previous research which states that performance expectancy has an influence on intentions to use, concreting the previous studies on UTAUT (Venkatesh et al., 2016; Lien et al., 2015; Slade, 2015; Lai, 2015; Okumus, 2016). In this case it is concluded that application performance such as practical, time saving, safety and productivity of OVO is an important factor why OVO students want to continue using OVO going forward.

Effort Expectancy can be said have no significant effect on Continuance Intention. This results are not in line with previous studies that effect positive relationship between effort expectancy and intentions to use (Lai, 2015; Okumus, 2016). In this case it can be concluded that the size of the effort expended by students in using OVO does not significantly influence the decision to continue using OVO going forward.

Price Saving Orientation can be said to have no significant effect on Continuance Intention. This study is in line with previous studies examined by (Lien et al., 2015) which mentions found negative effects on economic costs and intentions to use. Study conducted (Palau-Saumell, 2019) mentions that in this research, price value was replaced by the price-saving orientation. Price saving orientation has a significant influence on intentions (Escobar et al., 2014). These reveal that end consumers use these applications to get price cutting and to saving. In this case, it can be concluded that the price-saving orientation offered by OVO does not significantly influence the decision of OVO users to continue using OVO in the future, this is because lately the cashback offered by OVO has not been as big as the beginning of OVO appearing like paying Grab Rp.1, 30\% to 50\% cashback and at the same time, large OVO competitors such as DANA and GOPAY offer greater cashback.

Social Influence can be said to have significant effects on Continuance Intention. Social influence has been commonly tested in the mobile research, and its influence on intentions to use has garnered considerable support (Fortes and Rita, 2016; Lien et al., 2015). But in research conducted by (Palau-Saumell, 2019) indicated one of the least powerful drivers of intentions to use. Found in study (Okumus, 2016) conducted among users of diet apps in which social influence was the most powerful antecedent of the intentions to use. In this case it can be concluded that the people around OVO users urge each other to use OVO so that it affects the intention to use OVO going forward.

Facilitating Conditions can be said not significant on Continuance Intention. From the previous study, indicating the same result for the relationship among these variables. Especially on app-based mobile tour guides (Lai, 2015), and their effects on usage have also been tested among consumers of mobile shopping services (Fortes and Rita, 2016). In this case it can be concluded that the availability of facilities in the OVO application does not become an excuse for OVO students to continue using OVO going forward, in the sense that there is no special difference regarding OVO infrastructure compared to major 
competitors such as GOPAY and FUND, all depending on the connection on the user's mobile.

\section{CONCLUSION}

This research is expected to be able to provide various benefits for related parties, including for OVO e-payment companies. As a results, performance expentancy and social influence are both had impacts on the continuance intention to use OVO as part of their e-payment lifes.

This research can be used as a material for consideration and evaluation of the performance of OVO applications, for example reducing the possibility of errors such as failed scan or failed payment. Then the application synergy with the internet network must be both more synchronous. In addition, identification of various obstacles / problems faced by the company so far can be used as a reference for improvement and improvement of company performance in the future. In this research, maintenance on OVO must have prior notice and do not carry out maintenance during working hours. To be able to overcome the gray status constraints of OVO users who are still gray, it can be overcome by further improving services.

For e-payment companies this kind of research can be used as literature to understand the factors that influence continuance intention on e-payment. It can also be used in various e-payment terms revealed in the OVO experience which is expected to improve the services of other companies. Various obstacles revealed in this study can also be used as consideration in developing strategies to start an e-payment type business, because even though e-payment provides a good business prospect, it does not mean that the implementation does not face obstacles.

For academics, this research is expected to be used to enrich knowledge and complete the literature on the role of performance expectancy, effort expectancy, price saving orientation, social influence, and facilitating conditions on continuance intention.

This study has several limitations, namely the research variables used are only 6 of the 12 variables of UTAUT-2, such as the model in Figure 2.1, while there are many other variables that also affect continuance intention variables such as hedonic motivation, price value, habit, age. , gender, experience, behavioral intention and use behavior. This study takes variables that have a significant influence from Indrawati's previous research journal, 2019 regarding GOPAY. This study did not use the hedonic motivation, gender, age, and experience variables because in the Indrawati study, 2019 had insignificant results on continuance intention. Then this study also does not use habit variables because researchers prefer to use other variables such as price saving orientation, performance expectancy, social influence, and facilitating conditions. The use of the number of variables is limited in this study in order to save more time, because the research time is limited.

Second, regarding the sample of this study, only 200 respondents were selected from 239 google form respondents from 4 major universities and some non-student respondents in Banten province. Meanwhile, there are also several universities in Banten province that did not have the opportunity to fill out the research questionnaire, namely Bunda Mulia University, Pradita University, Matana University, Muhammadiah Tangerang University, Atmajaya University and others. 
Third, the time of this study was also relatively short, only 3 months, this less time affected the information that should have been given to readers of this study. The other side of the lack of time, this research is only one shot cross-sectional, which means that it is only carried out for a period (5 November 2019 - 11 November 2019) regardless of changes in the future.

From the results of the hypotheses in chapter four, this study informs that from the OVO side it would be fine to focus on building performance expectations and strong social influence in order to get sustainable intention on OVO.

Performance Expectancy: Making OVO more practical, making OVO more time consuming, providing more security and less energy, from that empathy, OVO's positioning in the expected performance is stronger. An application example is OVO being an application that looks simple, easy to implement, efficient in payments and transaction security is not trusted by OVO users.

Social Influence: Must be careful in building the brand image of OVO, if there are people who are satisfied or dissatisfied, then OVO users will talk about it. The application example is more interactive with consumers, one of which is to inform schedule maintenance, create a reciprocal user promotion reference code and increase the number of outlets that can use the OVO payment method. Of these four things, OVO's positioning in social influence is stronger.

\section{REFERENCES}

Elkhani, N., and Bakri, A. (2016). Review on " expectancy Disconfirmation theory " (EDT) model in B2C e-commerce. Journal of Information Systems Research \& Innovation.

Fortes, N., and Rita, P. (2016). Privacy concerns and online purchasing behaviour: Towards an integrated model. European Research on Management and Business Economics. https://doi.org/10.1016/j.iedeen.2016.04.002.

Kahneman, D., and Tversky, A. (2018). Prospect theory: An analysis of decision under risk. In Experiments in Environmental Economics. https://doi.org/10.2307/1914185.

Lankton, N. K., Harrison McKnight, D., Wright, R. T., and Thatcher, J. B. (2016). Using expectation disconfirmation theory and polynomial modeling to understand trust in technology. Information Systems Research. https://doi.org/10.1287/isre.2015.0611.

Lien, C. H., Wen, M. J., Huang, L. C., and Wu, K. L. (2015). Online hotel booking: The effects of brand image, price, trust and value on purchase intentions. Asia Pacific Management Review. https://doi.org/10.1016/j.apmrv.2015.03.005.

Liu, C. H. S., and Lee, T. (2016). Service quality and price perception of service: Influence on word-of-mouth and revisit intention. Journal of Air Transport Management. https://doi.org/10.1016/j.jairtraman.2015.12.007.

Martin, J. J., and Guerrero, M. D. (2020). Social cognitive theory. In Routledge Handbook of Adapted Physical Education. https://doi.org/10.4324/9780429052675-22.

Martins, C., Oliveira, T., and Popovič, A. (2014). Understanding the internet banking adoption: A unified theory of acceptance and use of technology and perceived risk application. International Journal of Information Management. https://doi.org/10.1016/j.ijinfomgt.2013.06.002.

MB.Alazzam, A. S. (2015). Review of Studies With Utaut As Conceptual Framework. 


\section{European Scientific Journal.}

Rizzo, T. L., and Columna, L. (2020). Theory of planned behavior. In Routledge Handbook of Adapted Physical Education. https://doi.org/10.4324/978042905267525.

Rogers, E. M., Singhal, A., and Quinlan, M. M. (2019). Diffusion of innovations. In An Integrated Approach to Communication Theory and Research, Third Edition. https://doi.org/10.4324/9780203710753-35.

Seiler, S. (2013). The impact of search costs on consumer behavior: A dynamic approach. Quantitative Marketing and Economics. https://doi.org/10.1007/s11129-012-9126-7.

Venkatesh, V., Thong, J. Y. L., \& Xu, X. (2016). Unified theory of acceptance and use of technology: A synthesis and the road ahead. Journal of the Association for Information Systems. https://doi.org/10.17705/1jais.00428.

Wang, F. (2014). Explaining the low utilization of government websites: Using a grounded theory approach. Government Information Quarterly. https://doi.org/10.1016/j.giq.2014.04.004.

Williams, M. D., Rana, N. P., \& Dwivedi, Y. K. (2015). The unified theory of acceptance and use of technology (UTAUT): A literature review. In Journal of Enterprise Information Management. https://doi.org/10.1108/JEIM-09-2014-0088.

Yeo, V. C. S., Goh, S. K., and Rezaei, S. (2017). Consumer experiences, attitude and behavioral intention toward online food delivery (OFD) services. Journal of Retailing and Consumer Services. https://doi.org/10.1016/j.jretconser.2016.12.013.

\section{ACKNOWLEDGEMENTS}

Thanks to Februarga and friends from Universitas Pelita Harapan for collecting data and help us to collect some theories. We also thanks all our affiliations for both direct and indirect impacts of our research. This includes Universitas Trisakti, Trisakti School of Management and Universitas Tarumanagara. 